\title{
Histological Studies of the Prenatal and Postnatal Development of the Ovary in the Golden Hamster (Cricetus Auratus)
}

\author{
By \\ Atsushi Nakano \\ Department of Anatomy, Nagoya University School of Medicine \\ (Director: Prof. Dr. Shooichi Sugiyama)
}

Numerous publications have been presented so far on histological and histogenetical studies of the ovaries of mammals including man (see $\mathrm{Nage} \mathrm{1,} \mathrm{1896;} \mathrm{K} \mathrm{öll} \mathrm{ike} \mathrm{r,} \mathrm{'02;} \mathrm{W} \mathrm{a} \mathrm{ld} \mathrm{e} \mathrm{y} \mathrm{e} \mathrm{r,} \mathrm{'06;} \mathrm{B} \mathrm{üh} \mathrm{le} \mathrm{r,}$ '06; Fischel, '29 and '30; Schröder, '30; Stieve, '30). Recently, Patzelt ('56) and Watzka ('57) have summarized extensively the data concerning this problem. The ovaries of rodents, as common laboratory mammals, have also been often subjected to these studies. However, the ovary of the golden hamster, which is included in the rodent, has not yet been studied histogenetically. This paper deals with the prenatal and postnatal histological development of this organ of this species, with special emphasis on the germinal epithelium and its derivatives and the interstitial cells. The author hopes also that this study will serve as a control for other experimental studies of the ovary of this species.

\section{Materials and Methods}

A total of 186 hamsters were used for this study, including 58 embryos ranging in age trom 10 days of gestation ( $6 \mathrm{~mm}$ CRL) to full term (16 days of gestation, $32 \mathrm{~mm} \mathrm{CRL}$ ), and 128 animals from immediately after birth to approximately 60 days. The materials were fixed in $\mathrm{Z}$ e n k e r's fluid, sectioned at $6 \mu$ transversely serially. Sections prepared were stained with $\mathrm{H}$ a $\mathrm{n}$ se n's hematoxylin and eosin, and some with $\mathrm{He}$ ide $\mathrm{nh}$ a in's azan stain or with Bielschowsky's silver impregnation for investigating the stroma. 


\section{Observations}

In the $6 \mathrm{~mm}$ CRL stage (10 days of gestation)-the primordium of the gonad appeared as a thickening of the celomic epitheliumgerminal epithelium-on the ventromedial surface of the mesonephros. The sex was not yet identifiable. The primordium indicated a few epithelial layers from which was proliferated a few cell groups towards the mesenchym (fig. 1). Epithelial cells were cubical or polygonal and showed no distinct cell boundaries. The nuclei were vesicular and of various sizes. The cytoplasm was finely granular but not abundant. Numerous mitotic figures were found in them.

A number of large oval or round cells-primitive germ cellswere found in the germinal epithelium and further in the underlying mesenchym and the mesentery (fig. 1). The nuclei were large and vesicular with a fine loose chromatin reticulum which contained one or two conspicuous nucleoli. The cytoplasm was abundant but less granular, and faintly eosinophilic. Their mitotic figures were also large in size.

The stroma extended from the mesonephros, still small in amount and was arranged parallel to the germinal epithelium. It consisted of mesenchymal cells and few fibrous elements (fig. 1). A few primitive capillaries were found here.

In the $9 \mathrm{~mm}$ CRL stage (11 days)-the growing primordium appeared as the genital ridge, marked off by two slight furrows, medial and lateral, from the mesonephros. Proliferation from the germinal epithelium prevailed as cell conglomerates over the whole gonadal area. The germinal epithelium remained unchanged, while the proliferating epithelial cells became slightly clearer. They had somewhat irregular-shaped nuclei with a very fine, loose chromatin reticulum and one nucleolus, and a faintly eosinophilic cytoplasm. The cell boundaries were indistinct.

Primordial germ cells increased in number by mitotic division but became slightly smaller than before and had more eosinophilic cytoplasm. The vesicular nuclei had a denser chromatin reticulum, but contained conspicuous nucleoli. They were no longer found in the mesenchym and the mesentery, but only in the germinal epithelium and its proliferating cell conglomerates.

The stroma increased in amount. Mesenchymal cells were arranged in layers near the surface of the primordium, but irregularly in the deep part. Some extended with increasing capillaries, between 
cell conglomerates of the germinal epithelium.

In the $11 \mathrm{~mm}$ CRL stage (12 days)-the two sexes became slightly distinguishable by the histological changes of the primordium. The growing primordium of the female gonad became an ovoid body, constricted from the mesonephros by deepening medial and lateral furrows. In so doing, the primitive mesovarium and hilus were formed in this stage.

Primordial germ cells increased far more in number. A few of them became giant-sized with enormously swollen, faintly eosinophilic, vesicular nuclei and eosinophilic cytoplasm. Degeneration began to occur in primordial germ cells-the nuclei became dark and finally pyknotic, and the cytoplasm intensely eosinophilic. The stroma increased, but still less just beneath the germinal epithelium and between its proliferating cell conglomerates, whereas it was abundant near the hilus. Capillaries also increased in number.

In the primordium of the male gonad, the stroma increased markedly just beneath the germinal epithelium and became lamellar, suggestive of the formation of a primitive tunica albuginea, which separated proliferating cell conglomerates from the germinal epithelium. The conglomerates were now in the process of forming the male sex cords.

In the $14 \mathrm{~mm}$ CRL stage (13 days)-the germinal epithelium became single-layered in a small part. Proliferating cell conglomerates developed now into anastomosing cords-medullary cords-in the deep part of the primordium, while they remained as such beneath the germinal epithelium. The medullary cords were seen connecting. with the cell conglomerates. Primordial germ cells increased and were abundantly distributed in the germinal epithelium, its conglomerates and medullary cords. Their giant forms were sometimes found. Degeneration continued in these primordial germ cells.

The rete ovarii was found as conglomerates of epithelial cells in the hilar zone and extended towards the mesovarium. The nuclei were rich in chromatin and the cytoplasm was small in amount. It contained no cavity.

The stroma increased in amount. Beneath the germinal epithelium, the mesenchym became arranged somewhat densely while it was still loosely arranged in the deep part.

In the $21 \mathrm{~mm}$ CRL stage (14 days)-the primordium grew further. The germinal epithelium was a single cubical epithelium over a major part and a single squamous epithelium over a small part, but 
still proliferated. The cell conglomerates proliferating from it developed now into cords-cortical cords-by invasion of connective tissue and capillaries (fig. 2). The cortical cords showed various forms and sizes, which were seen separating further into thinner cords by connective tissue. Some of them became connected with medullary cords. Oogonia were distributed not only in the germinal əpithelium but also in the cortical and medullary cords (fig. 2) and increased by mitotic division. The oogonia maintained almost the same histological appearance as the primordial germ cells in the previous stage (fig. 2). Degeneration occurred in them. Their giant forms were rare. The stroma increased, but fibrous elements were not yet produced in abundance (fig. 2).

In the $28 \mathrm{~mm} C R L$ stage (15 days)-the germinal epithelium became a single squamous epithelium over a major part, but remained stratified over a small part, suggesting proliferation. Cortical and medullary cords were seen separating into groups of cells-egg clusters, in which several oogonia were contained (fig. 3). Oogonia still continued mitotic division and degeneration. The degeneration, however, took place rather more frequently in the medullary cords. Some oogonia began to grow. The nuclei were round and the chromatin was diffusely distributed. The cytoplasm became clearer than before.

The tunica albuginea was formed, although incompletely. Connective tissue was arranged in several layers here and was seen separating cortical cords and egg clusters from the germinal epithelium (fig. 3).

In the $32 \mathrm{~mm}$ CRL stage (16 days)-the primordium grew further. The germinal epithelium was a single squamous epithelium over the major part but remained proliferative in the part forming cords and egg clusters which contained oogonia. Cortical and medullary cords became more slender and smaller and some of them separated into egg clusters. Oogonia became large and clear. Some oogonia were still in a state of mitotic division. Degeneration continued in them, especially in those of the medullary cords.

The rete ovarii was found in almost the same condition as before.

Immediately after birth - the germinal epithelium was a single squamous epithelium over the major part. Its proliferation-new formation of cords and egg clusters-became reduced in degree, and did not extend beyond the tunica albuginea-the cords and egg clusters remained as small invaginations (fig. 6). 
Oogonia were large and clear. Degenerative and mitotic figures became markedly reduced in number in them. In this stage, a considerable number of the oogonia started to enter the beginning stage of meiotic division-the leptotene stage, and thus at the same time they may be called oocytes. The cell bodies and nuclei enlarged further. The chromatin was arranged in thin threads interlacing in the nuclear space. These oocytes were found in the germinal epitheliurn and its invaginations, cortical cords, medullary cords and their egg clusters.

The rete ovarii indicated no marked change.

At one to three days-the germinal epithelium became completely a single squamous epithelium, but retained small invaginations with oogonia. Some of the invaginations were connected with cortical cords. Medullary cords became more slender and smaller.

Oogonia decreased in number while oocytes increased rapidly in number on entering the beginning stages of meiosis (fig. 4). Most of the oocytes were found in the synaptene stage-chromosomal threads were arranged in winding form at one pole of the nucleus, often joined to one another side by side. At three days some oocytes entered the pachytene stage. These oocytes were found not only in the medullary and cortical cords, but also in the germinal epithelium and its invaginations. Degeneration occurred also in them and especially numerously in those of the medullary cords which became slender and smaller.

The rete ovarii was found as a cord containing a cavity in the hilar zone. The wall was composed of a single layer of columnar cells, which were sometimes in a state of mitosis. The nuclei were oval and chromatic. The cytoplasm was strongly eosinophilic.

The stroma increased in amount and connective tissue cells became mature.

At 4 days-cortical cords showed a trend for increasing separation into egg clusters. Medullary cords became more slender and smaller than before. Oocytes were in advanced stages of meiosis, the majority of them in the pachytene stage and some in the diplotene stage. Degeneration occurred numerously in oocytes of the medullary cords. No oogonia were found.

At 5 days-the germinal epithelium still showed small invaginations. Oocytes still showed meiosis-the majority of them in the diplotene stage and some in the pachytene stage. A significant change occurred in some oocytes which reached the diplotene stage. 
The oocytes did not enter further advanced stages but rather a resting interval, and came to have a large vesicular nucleus with a conspicuous nucleolus and an eosinophilic large cell body. Each of them was contained in a far smaller egg cluster with several ordinary epithelial cells, which was gradually separated from large egg clusters and cords by invasion of argyrophilic fibers. Degeneration occurred in oocytes in meiosis as well as in a resting interval (fig. $5)$, and especially numerously in those of the cortex. The nuclei were intensely eosinophilic, and the cytoplasm also strongly eosinophilic and in a state of shrinkage. Oocytes disapreared in medullary cords.

The rete ovarii grew in size and was branched.

At 6 days-medullary cords became more slender and smaller, and consisted exclusively of ordinary epithelial cells without oocytes. Cortical cords only stood out in the ovary, but were now separating into smaller egg clusters.

Oocytes were still in the diplotene stage in the superficial zone of the cortex, while they were already in rest in the deep zone and began to form an initial arrangement of the primary follicles with a change of ordinary epithelial cells (fig. 5). Degeneration occurred in these oocytes. The ordinary epithelial cells became flattened, with an oval nucleus, which contained a moderately dense chromatin reticulum and indistinct nucleoli, and a clear, less granular cytoplasm, and began to surround the oocytes as follicular cells (fig. $5)$. The cell boundaries were still indistinct.

The rete ovarii grew extending from the hilus towards the mesovarium and was branched.

At 7 days-the germinal epithelium still possessed small invaginations, some of which connected with cortical cords. Medullary cords almost disappeared, but some residuals were found as small cords connecting with the rete ovarii.

Oocytes indicated a step-wise differentiation pattern in the cortex. In the superficial zone they were generally in the diplotene stage, in the deep zone in rest and in the deepest zone in forming the primary follicles. Some primary follicles were in degeneration-the formation of spaces between the follicular epithelium and stroma, vacuoles in the nuclei and cytoplasm of oocytes, with shrinkage and strongly eosinophilic staining of their cell bodies.

At 8 days - the germinal epithelium had still small invaginations containing oocytes. The cortex grew and was filled numerous grow- 
ing primary follicles. Cortical cords and their egg clusters remained in small numbers only just beneath the germinal epithelium. Medullary cords disappeared completely. Oocytes of the diplotene stage were distributed in small numbers in the germinal epithelium and its invaginations. Many oocytes were in rest and now grew in grown primary follicles. Surrounding follicular cells increased in height and multiplied by mitotic division. This change of the primary follicles started in the deep zone of the cortex and extended toward the superficial zone. Some primary follicles degenerated in the same manner as found before.

Connective tissue and blood vessels increased further and some connective tissue began to form the theca folliculi and was arranged in layers around grown primary follicles of the deep zone of the cortex.

From 10 to approximately 20 days-the germinal epithelium and its small invaginations showed no mitotic figures nor meiotic figures. In them primary follicles were still growing (fig. 6). At 10 days, the germinal epithelium of the hilus indicated increased invagination which was maintained until 20 days.

The cortex changed in appearance (fig. 6). Primary follicles were found in the superficial zone of the cortex and growing follicles in the deep zone. Primary follicles were often in degeneration, especially in invaginations of the germinal epithelium of the hilus. There occurred sometimes follicles containing several (two to 6) oocytesmultiovular follicles-in the deep zone, which increased in number further at 20 days. A 15 days, oocytes of growing follicles began to have a strongly eosinophilic homogeneous oolemma, and were surrounded by a primitive corona radiata (fig. 6). Follicular cells became smaller with chromatin-rich round nuclei in process of stratification by frequent mitotic division. Follicular cells of some grown primary follicles very rarely resembled young oocytes and had somewhat enlarged nuclei and eosinophilic enlarged cell bodies. At 18 days, the theca folliculi developed into two layers, theca interna and externa, in some growing follicles. In the internal layer, connective tissue cells became polygonal and clear with a round chromatin-poor nucleus-theca interna cells, and often were in mitotic division. In the external layer they remained as such. Capillaries were found in more abundance in the internal layer.

A change began to occur in some connective tissue cells of the hilus from 12 days on-they were transformed into large round or 
oval cells with a round eosinophilic nucleus and an eosinophilic granular cytoplasm-interstitial cells (fig. 7), and were easily distinguishable from the theca interna cells and folljcular cells. They increased by mitotic division (fig. 7) and were distributed singly or in groups in both the cortex and medulla.

The rete ovarii was a branched acinous tube extending from the hilus to the mesovarium.

Blood vessels developed better than before and were larger in size in the medulla. Capillaries were distributed widely throughout the entire extent of the ovary, and especially abundant in the theca interna and interstitial cell conglomerates. A number of smooth muscle fibers extended from the hilus towards the medulla.

At approximately 25 days-the germinal epithelium had invaginations, especially in the hilus. Primary follicles were found in these invaginations and just beneath the germinal epithelium. The cortex was in major part filled with further growing follicles but contained no vesicular follicles (fig. 8). Oocytes also grew in size and came to have a more distinct, thicker, eosinophilic oolemma (fig. 8). Follicular cells became more stratified (fig. 8) by very frequent mitotic division. In some growing follicles, stratified follicular cells became loose in connection and had small spaces filled with eosinophilic material between them-bodies of Call-Exner (fig. 8).

Involution-atresia-occurred in some grown follicles. In these follicles, oocytes indicated yet no marked signs of degeneration but only a peripheral displacement of the nucleus, while follicular cells showed caryorrhexic and pyknotic nuclei. Furthermore, some spaces which were filled with cell debris and histiocytes, were found between them. The theca folliculi still remained intact.

The stroma increased further in amount but was arranged loosely. Blood vessels and capillaries also developed and increased in number. Smooth muscle fibers extended from the hilus towards the medulla.

At approximately 28 days-the germinal epithelium remained still in almost the same condition as before. The cortex indicated an initial sign of the adult form; primary follicles were found in small numbers just beneath the germinal epithelium and moderately grown follicles rather in the deep zone. A number of grown vesicular follicles extended towards the superficial zone of the cortex (fig. 9) and, in so doing, occupied the whole thickness of the cortex and further protruded on the surface of the ovary.

Now, the follicular epithelium of vesicular follicles may be called 
the membrana granulosa, and that of grown vesicular folliclesGraafian follicles-was very thin-in a few layers-in the outer part corresponding to the stigma and massive in the cumulus oviger (fig. 9). Cranulosa cells had somewhat chromatin-poor, vesicular nuclei and were larger than follicular cells and showed distinct cell boundaries. Further, just before rupture they came to have abundant eosinophilic granules around the nucleus and sometimes vacuolated at the periphery. Mitotic division was no longer found in them. A layer of columnar cells persisted, attached directly to the oolemma, and thus the corona radiata was definitively formed. The theca folliculi developed also with the growth of follicles. The theca interna consisted of a few layers of theca interna cells and thickened in an inner zone corresponding to the cumulus oviger. The theca interna cells had a round chromatin-poor nucleus and a cytoplasm clearer than that of granulosa cells (fig. 9), and were often in mitotic division.

Atresia continued in numerous follicles, growing and vesicular, (fig. 10) and in multiovular follicles. Most of the multiovular follicles used to degenerate before they became vesicular. The more numerously oocytes were contained in a follicle, the more rapidly the follicle degenerated. The degeneration started first in oocytes and extended towards the follicular or granulosa epithelium but sometimes in a reverse manner. Degenerating oocytes showed various signs such as hyperchromatosis of nuclear membranes or caryorrhexis, shrunken cell body, and wavy oolemma. Some of them floated in the follicular cavity without the corona radiata and soon disappeared. Still other degenerating oocytes showed the first polar spindle or the second spindle with a polar body (fig. 10). Degeneration of granulosa cells started near the follicular cavity and around the oocytes as caryorrhexis, pyknosis of the nuclei and clear swelling of the cell bodies, and extended towards the periphery. Histiocytes were sparsely distributed in these areas and further in cavities, which contained degenerating cells. Atretic growing follicles did not form a cavity. The theca folliculi of atretic follicles became thicker than normal. Theca interna cells came to have somewhat irregularly round chromatin-rich nuclei and clear bodies (fig. 10), and were often in mitotic division. In the theca interna capillaries increased in number. Histiocytes and argyrophilic fibers were found here.

The rete ovarii was seen as a branched acinous tube in the 
hilus. Smooth muscle fibers continued no longer to extend from the hilus towards the medulla. Smooth muscle fibers which extended earlier remained as an usual component of the medulla until later.

At 30 days-the ovary grew further and showed an uneven surface due to protrusion of vesicular follicles and occurrence of corpora lutea. The germinal epithelium maintained almost the same condition as seen before. The cortex was now changing in appearance-a number of grown vesicular follicles were just before rupture, and some corpora lutea were still fresh but some already in an advanced stage of development (figs. 12 and 13). The walls of the ruptured follicles collapsed. The membrana granulosa was thrown into folds. The follicular cavity had now an irregular shape, containing more or less extensively blood clots, plasma, liquor and histiocytes, and gradually became reduced being filled with loose connective tissue. At the base of the folds the theca interna gathered in masses, while between the folds it was scarce. Granulosa cells hypertrophied, and had round or oval chromatin-poor swollen nuclei with a few distinct nucleoli. Some were bi- or trinucleated. The cytoplasm became vacuolated. In so doing, the granulosa cells became lutein cells, which were arranged in radial cords. Theca interna cells developed into lutein cells, which were smaller in size than granulosa lutein cells. The nuclei were also smaller round, and somewhat more chromatic, and the cytoplasm was more vacuolated. Capillaries and connective tissue including argyrophilic fibers invaded the layer of the granulosa lutein cells which showed numerous spaces between them (figs. 12 and 13). Connective tissue invading earlier here formed a layer covering the inner surface of the granulosa.

Atretic vesicular follicles were in a further advanced stage of degeneration and persisted transiently in a cystic state (fig. 11). Some oocytes had wavy oolemma and others were floating within the cavity. Still others completely disappeared and only a wavy oolemma ramained. Many granulosa cells were just about to disappear and some were devoured by histiocytes. The nuclei were caryorrhexic and pyknotic, or swelling. The basement membrane thickened in width and became hyaline. The theca interna rather thickened and was separated into cords by connective tissue. Theca interna cells increased by mitotic division and grew in size. They indicated somewhat irregular-shaped chromatic nuclei and clear cell bodies.

At 33 and 35 days-the germinal epithelium maintained still invaginations. The tunica albuginea remained less developed and 
still consisted of a few layers of connective tissue. Corpora lutea showed various signs of regression. The corpora was reduced in size by atrophy and degeneration of granulosa lutein cells which were more marked in the inner layer of the walls. The granulosa lutein cells were more vacuolated and their nuclei were pyknotic, and were invaded by connective tissue cells of the theca externa and histiocytes. The connective tissue cells formed reticulums in the corpora. At 35 days some corpora lutea indicated an initial stage of the corpus fibrosum, in which granulosa lutein cells remained in the periphery. Later, theca lutein cells shrunk, became indistinguishable from degenerating granulosa lutein cells, and disappeared. Some of them returned to connective tissue cells.

At 35 days - a significant change occurred in advanced forms of the atretic follicles. The basement membrane showed hyaline degeneration. Theca interna cells developed into interstitial cells, which had somewhat irregular-shaped nuclei with a few nucleoli, and clearly vacuolated bodies (fig. 14). They were radially arranged, separated by connective tissue, and prevailed over the medulla. Accordingly, two kinds of interstitial cells existed in the stroma in this stage. The others were of connective tissue cell origin. The rete ovarii remained in almost the same condition as before. Blood vessels developed markedly in the stroma and especially in the medulla.

At 38, 40 and 45 days - the germinal epithelium still maintained small invaginations, especially in the hilar zone. A small number of primary follicles still remained just beneath the germinal epithelium. The cortex contained numerous follicles of different grades of growth, corpora lutea and their degenerating forms. In some of the fully grown vesicular follicles, oocytes showed a polar spindle. A number of corpora lutea were transformed into corpora fibrosa at 38 days through step-wise degeneration of granulosa lutein cells extending from the center to the periphery (fig. 15) and shrinkage of theca lutein cells. Connective tissue which invaded the corpora fibrosa underwent hyaline degeneration, especially in the central part at 40 days-the formation of corpora albicantia.

Interstitial cells of theca interna cell origin increased by mitotic division and increase of atretic follicles, and prevailed from the cortex towards the medulla and hilus, while those of connective tissue cell origin decreased in number.

At 50,55 and 60 days-primary follicles remained just beneath 
the germinal epithelium. The cortex indicated almost the same distribution of follicles, corrora lutea and their degenerating forms. Multiovular follicles were also degenerating and disappeared completely at 60 days. Interstitial cells of connective tissue cell origin decreased through degeneration and in part return to connective tissue cells towards 55 days and disappeared at 60 days, while those of theca interna cell origin increased further with an increase of atretic follicles, and were found as numerous cell islets of different shapes and sizes, broken up by ingrowth of connective tissue, in the cortex and medulla. Afterwards they decreased also through degeneration and in part reversion to connective tissue cells.

The rete ovarii remained in almost the same condition as was found before.

\section{Discussion}

Development of ovary-The time of appearance on the ventromedial surface of the mesonephros of the gonadal primordium has been reported in different mammals (man-8-12 mm $\mathrm{N}$ a g el 1896, $7 \mathrm{~mm} \mathrm{Fischel} \mathrm{'30} \mathrm{and} \mathrm{Hig} \mathrm{u} \mathrm{ch} \mathrm{i} \mathrm{'32,} 8 \mathrm{~mm} \mathrm{Gil} \mathrm{m} \mathrm{a} \mathrm{n} \mathrm{'} 48$; guinea pigs $-9 \mathrm{~mm} \mathrm{R} \mathrm{u} \mathrm{b} \mathrm{schkin} \mathrm{'12;} \mathrm{rabbits-12} \mathrm{days} \mathrm{of} \mathrm{gestation} \mathrm{T}$ aj i ma ' 36 ; pigs $-7 \mathrm{~mm} \mathrm{~A} 1 \mathrm{le} \mathrm{n} \mathrm{'04;} \mathrm{cats}-5.4 \mathrm{~mm} \mathrm{~K} \mathrm{i} \mathrm{m} \mathrm{u} \mathrm{r} \mathrm{a} \mathrm{'59).} \mathrm{It}$ is found in hamsters that the primordium appears as a thickeninga few layers-of the celomic epithelium on the same place in the $6 \mathrm{~mm}$ CRL stage (10 days of gestation) (fig. 1) and as the genital ridge in the $9 \mathrm{~mm}$ stage (11 days).

A step-wise differentiation of the germinal epithelium has been also described in relation to its proliferation. Winiwarter et al. ('00, '09) found 1 . the formation of the medulla by producing medullary cords from the germinal epithelium, 2. the formation of the primitive cortex and 3 . the formation of the definitive cortex by epithelial invagination from the germinal epithelium in embryonic ovaries of rabbits, cats and man. Felix ('11) stated two stages in women-the formation of the "Epithelkern" derived from the germinal epithelium, which does not contribute to form the ovary, and the formation of the "neogene Zone" to contribute definitively to the ovary. Gr ünwald ('34) pointed out also two stages in some mammals-the formation of primary cords to degenerate soon, and that of secondary cords to contribute to the definitive ovary.

Also in hamsters, there occurs a step-wise development of the 
germinal epithelium and its derivatives-1. the indifferentiation stage (6-11 $\mathrm{mm}, 10-12$ days of gestation) in which the primordium indicates no sex and consists of cell conglomerates proliferating from the germinal epithelium throughout the whole area, 2. the preparatory differentiation stage subdivisible into two parts, the first (about 14$21 \mathrm{~mm}, 13-14$ days) in which the cell conglorrerates develop into cords in the deep zone of the primordium-medullary cords in the $14 \mathrm{~mm}$ stage and in the superficial zone-cortical cords in the $21 \mathrm{~mm}$ stage (fig. 2), and the second (about 28-32 mm, 15-16 days) in which medullary and cortical cords are seen separating into egg clusters (fig. 3), and 3. the definitive differentiation stage from directly after birth onwards in which oogonia change to oocytes passing through the initial stage of meiosis with the formation of follicles, and the proliferation of the germinal epithelium is now arrested by the developed tunica albuginea and remains as small invaginations. In these stages, primordial germ cells in the germinal epitheliumoogonia are gradually added in order by mitotic division to the cell conglomerates, medullary and cortical cords and egg clusters. Degeneration begins in primordial germ cells-oogonia-from the end of the indifferentiation stage and continues in oogonia and oocytes until later.

The medullary cords present some problems concerning their development. In agreement with the data of $\mathrm{J}$ a n o s i k (1885, some mammals), Coert (1898, rabbits and cats), Sk r o ba n s k y ('03, pigs), B üh le r ('06, women) and $\mathrm{S}$ a k a i d a ('32, guinea pigs), it is doubtless that the medullary cords of hamsters are produced from the cell conglomerates of the germinal epithelium by ingrowth of the mesenchym in the deep zone of the primordium. Some authors (van B e e k, '24, cows; Fis ch el, '30, women), however, stated them to be of mesenchym cell origin. The medullary cords may to some extent correspond to primary sex cords of $\mathrm{Gr}$ ü n wald ('34, some mammals) who distinguished them from secondary cords by the lack of primordial germ cells, more slender shape and darker staining. The medullary cords of hamsters are somewhat different from his primary cords and contain primordial germ cells in abundance in earlier stages (fig. 2) but lose them later due to more frequent degeneration. According to $\mathrm{S}$ a k a id a ('32, guinea pigs), although transitorily proliferating in reticular arrangement, the medullary cords become indistinguishable from connective tissue cells, as a result of atrophy and loss of epithelial character, and remain as 
small groups of cells between follicles and in the zona vasculosa at 10 days after birth. He pointed out further their close connection with the rete ovarii in their development. The medullary cords of hamsters disappear completely soon (at 8 days after birth) after oocytes are lost in them at 5 days after birth, and do not change into connective tissue and interstitial cells.

The cortical cords present some problems concerning their development. Waldeyer (1870, some mammals) and Grünwald ('42, some mammals) described that the inward proliferation of the germinal epithelium produces them with the outward invasion of mesenchym. Janosik (1885, some mammals) described them to proliferate as such from the germinal epithelium. On the other hand, Fis chel (' 30 , women) insisted that conglomerates of mesenchymal cells develop into cortical cords in situ. Felix ('11, women) pointed out the peripheral occurrence of the "neogene Zone" which produces cortical cords by invasion of connective tissue after the formation of medullary cords. The cortical cords of hamsters are produced in the same way as in the formation of medullary cords. It is of interest that the formation of cords is centrifugal-first in the deep zone of the primordium-medullary cords and second in the superficial zone-cortical cords.

The postembryonic proliferation of the germinal epithelium of hamsters is arrested by the formation of the tunica albuginea, and remains merely as small invaginations without extending over this layer. W i n i wa r ter et al. ('00, rabbits and women; '09, cats) found also this sort of proliferation-Invagination épithéliale-and regarded it as the tertiary proliferation which supplies additional material for the primary cortex but later incorporates into a cortical material. Rubaschkin ('12) found new invaginations without any relation to cortical cords already in the $51 \mathrm{~mm}$ embryonic stage of guinea pigs. It is of further interest in hamsters that these invaginations increase temporarily at about 10 days after birth in the hilar zone and persist until 20 days, but most oocytes contained in them are degenerative. Burkl ('55) also reported the invaginations which contain ova rarely in the same place of adult hamsters. The cyclic activity of proliferation was found in the germinal epithelium of rabbits ( $\mathrm{D} \mathrm{u} \mathrm{ke,} \mathrm{'41)} \mathrm{and} \mathrm{in} \mathrm{the} \mathrm{epithelial} \mathrm{cords} \mathrm{of} \mathrm{dogs}$ (B a rto n, '45), but the present data shows no cycle in the invaginations of hamsters.

Germ cells-A number of investigators have insisted the existence 
of a germ track in mammals. Fis chel ('29) described primordial germ cells to be first found in a mass of undifferentiated cells at the posterior end of the primitive streak in man, and $\mathrm{H} \mathrm{a} \mathrm{m} \mathrm{lett} \mathrm{('35)}$ ventral to the mid gut in man. Chiquo in e ('54) found them in mouse embryos of 8 days at the posterior end of the primitive streak, and Kimura (' 59 ; in the dorsal epithelial wall of yolk sac in cat embryos. These germ cells have been said to migrate through the mesenchym to the root of the mesentery and to enter the celomic epithelium of the primordium ( $\mathrm{Fuss}$, '12, rabbits and pigs; Fischel, '30, man; Politzer, '33, man; Hamlett, '35, man; Ever et t, '43, mice; J u n g, '37, pigs; W it s c hi, '48, man; N i e u wk o o p, '49, vertebrates; C h i q u o in e, '54, mice; K i mura, '59, cats).

Some authors (Alle n, '04, some mammals; King s bury, ' 13 , cats; Sakaida, '32, guinea pigs) considered them as primary primordial germ cells which soon completely degenerate, and rather emphasized the development of secondary primordial germ cells from the germinal epithelium or its cords. The present study indicates that some primordial germ cells are extraregionally present in the indifferentiation stage but soon disappeared. Their origin and fate remain undetermined and require further examination. The development of the primordial germ cells from the germinal epithelium and its cords (W a l d e y e r, 1870, some mammals; $\mathrm{N}$ a g e l, 1896, women) is still supported by $\mathrm{Simkins}$ ('23, mice and rats), Hargitt ('25, rats) and van B e e k ('24, cows).

The further development of the primordial germ cells is also a subject of discussion. Skrobansky ('03, pigs) considered them as oogonia, in the onset of conversion from the indifferent primordium to the female primordium, and the oogonia just entering the growth period as primary oocytes. S chröder ('30, women) called ova entering the growth period oogonia and grown oogonia primary oocytes. $\mathrm{W}$ a t $\mathrm{z} \mathrm{k}$ a (' 57 , women) also called the grown oogonia primary oocytes. Sakaida ('32, guinea pigs) described different characteristics of these cells that primordial germ celis have large vesicular, sometimes lobated, chromatin-poor nuclei and large clear cell bodies with pseudopodia, oogonia having round or oval, chromatin-rich nuclei and smaller eosinophilic bodies, and primary oocytes represent the oogonia just entering the beginning of meiosis. The present results partly agree with those of $\mathrm{Sak}$ a ida. Primordial germ cells in the indifferentiation stage develop soon $(9 \mathrm{~mm})$ into smaller forms having round to oval nuclei with denser chromatin reticulums and eosinophilic cell 
bodies, and later are called the oogonia in the middle $(21 \mathrm{~mm}$ ) of the preparatory differentiation stage, at which stage cortical cords are produced. Just before birth, these oogonia grow to large forms with large clear nuclei having lightly distributed chromatin and clear cell bodies, probably after final mitotic division, and immediately after birth, develop to primary oocytes just entering the beginning of meiosis. In the early embryonic stages of hamsters there occur sometimes giant forms of primordial germ cells. In agreement with $\mathrm{Sakaida's} \mathrm{view} \mathrm{it} \mathrm{is} \mathrm{supposed} \mathrm{that} \mathrm{they} \mathrm{may} \mathrm{have} \mathrm{grown} \mathrm{due} \mathrm{to}$ delayed mitotic division. The oocytes in beginning meiosis have been described in rabbits by $\mathrm{W}$ in i warter ('01) and $\mathrm{Duke}$ ('41), in mice by $\mathrm{Kingery}$ ('17), in guinea pigs by $\mathrm{R} \mathrm{ubaschkin} \mathrm{('12)}$ and $\mathrm{Sak}$ a id a ('32), and in rats by Butcher ('27) and Pratt et al. ('17). Winiwarter found leptotene, synaptene, pachytene and diplotene stages but no further advanced stages of meiosis. It is found also in hamsters that primary oocytes begin to enter a stage of rest immediately after the diplotene stage and come to have large nuclei with loosely distributed thin threads of chromatin and faintly eosinophilic large cell bodies at 6 or 7 days after birth. It is supposed that before 10 days almost all of the primary oocytes, even those found in the germinal epithelium and its invaginations pass through the beginning stages of meiosis and enter a stage of rest. It is observed in hamsters that no mitotic nor mejotic figures are found in ova after 10 days.

$\mathrm{W}$ in i warter et al. ('09) pointed out in cats three stages of proliferation of ova together with meiotic divison-before birth, immediately after birth and just before puberty, but emphasized that the third stage only serves to produce definitive ova. King s b u r y ('13) rejected the tertiary proliferation in cats. Kingery ('17) found in cows that after birth the germinal epithelium can supply ova for degeneration of those produced in embryonic life but loses its ability in adults. A rai ('20) observed in rats that active proliferation of ova is maintained from the second to 9 th weeks after birth and continues to a lesser degree for one year, while ova produced in embryonic life all degenerate. V a n B e e k ('24) found in young cows that the germinal epithelium which enters a stage of rest just before birth begins the second proliferation to supply ova to a lesser degree and ceases to do so at 6 months. S a k a i d a ('32, guinea pigs) observed three divisions of ova in relation to the proliferation of the germinal epithelium - the first two divisions de- 
generate completely 1 . in the first half of embryonic life and 2 . before puberty; the third division-definitive ova-are supplied by the tertiary proliferation. Evans et al. ('31, some mammals) insisted that all the ova having developed before puberty degenerate, while ova found after puberty are supplied by cyclic proliferation of the germinal epithelium in coincidence with the ovarian cycle.

The present results reveal the following and differ from the data of Sakaid a and Evans et al.. 1. Ova-oogonia and oocytes -contained in medullary cords and their clusters degenerate completely by 6 days after birth, while 2 . those contained in cortical cords and their clusters also degenerate but some survive to develop. 3. Oogonia and oocytes are less numerous in the germinal epithelium and its proliferated invaginations than in cortical coras and their clusters, and are often seen degenerating especially in the invaginations of the hilar zone. These invaginations may be suggested as the tertiary proliferation although feeble in intensity. They indicate no cyclic activity coincident with the sexual cycle.

The rete ovarii-There are two different views concerning its origin-the developments from the celomic epithelium and from the mesonephros. The development from the celomic epithelium has been differently reported-from 1. free ends of sex cords running towards B ow ma n n's capsule ( $\mathrm{J}$ a n o s i k, 1890, some mammals), 2. the rete blastem derived from the celomic epithelium (C o e r t, 1898, rabbits), and 3. the cell cords arising from the celomic epithelium of the cranial part of the genital ridge, which runs towards the Malpighi's corpuscles (B ühler, '06, women). Winiwarter ('10, women) stated that it develops from B ow ma nn's capsules. The rete cord of hamsters appears first as a conglomerate of epithelial cells with chromatic nuclei and scanty cytoplasm in the hilar zone at the beginning of the preparatory differentiation stage $(14 \mathrm{~mm})$, as a tube shortly after birth and remains as a branched acinous structure even at 60 days. It is of interest that the rete rarely connects with residual medullary cords but never with the mesonephritic tubules. This finding may suggest that cell conglomerates from the germinal epithelium develop in part into the rete in the indifferentiation stage. Wilson ('26) found in man that the rete cords connect earlier with Wolffian glomeruli and later with medullary cords. It is found further in disagreement with $\mathrm{Sak}$ a ida's data that the rete of hamsters contains no ova.

The development of follicles-is centrifugal in hamsters, with 
gradual differentiation of the oolemma, follicular epithelium and theca folliculi-follicles in the deeper zone of the cortex are more advanced in differentiation.

The oolemma-There are three different views concerning its development. Marshall ('10) interpreted it to be a cuticular secretion of ova in lower vertebrates, Strass man n ('33, women) to be a secretion of follicular epithelium, and $\mathrm{K}$ i n g s b u r y ('39) to be of follicular epithelium origin in cats. Recently, Cha udhry ('56) divided it into two, zona radiata externa of follicular epithelium origin and interna of ooplasmic origin in teleosts. K öll i k e r (1898) found it in primary follicles in some mammals. Ki t a j i ma ('34c, women) demonstrated it rarely in primary follicles but usually in follicles with stratified follicular epithelium. Nagel (1888, women). described that it appears in well-prepared ova.

In hamsters it is found that the oolemma begins to appear in growing follicles at 15 days after birth and develop with stratification of the follicular epithelium. This may suggest that the oolemma has some intimate relation in its origin with the development of the follicular epithelium.

Follicular epithelium-The development of follicular epithelium includes some discussion. One is of germinal epithelium origin (W a l d e y e r, 1870 , some mammals ; Kölliker, '02, some mammals ; Okamoto, '28, dogs; Sakaida, '32, guinea pigs) and the other of mesenchym origin (F i s chel, '30, women). The present data reveal that it develops from indifferent ordinary cells of the germinal epithelium and its proliferations (conglomerates, medullary and cortical cords, clusters and invaginations) (figs. 2 to 4 ) and begins to. appear as a single layer of flat cells in primary follicles at 6 days (fig. 5) and become cubical to columnar (fig. 6). This agrees with the data of Kölliker ('02, some mammals) and Tajima ('36, rabbits). Kit a jima ('34a, women) pointed out the occurrence of a layer of oval cells before a layer of flat cells appears. In hamsters, mitotic division begins to occur in cubical follicular cells but not in flat ones. $\mathrm{Nag}$ e $\mathrm{l}$ (1888, women) found the division already in squamous follicular cells.

Stratification of follicular epithelium in growing follicles presents some discussion. It occurs by mitotic division (Köllike r, '02, some mammals; T a ji ma, '36, rabbits) or by apposition (O k amoto, '28, dogs). Sakaida ('32, guinea pigs) found apposition occurs always in the medulla and at least in the undifferentiated. 
cortex, but mitotic division only in the well-formed cortex. In hamsters, stratification occurs by mitotic division of the follicular cells, by which they become smaller with chromatin-rich nuclei and arranged densely (figs. 6 and 8). Later, the stratified follicular epithelium becomes loose with formation of the follicular cavity and develops to the membrana granulosa, which is thin in the outer part-stigma-of vesicular follicles and massive in the cumulus oviger (fig. 9). The granulosa cells enlarge with chromatin-poor vesicular nuclei and show distinct cell boundaries, and further just before rupture, come to have abundant granules around the nuclei and sometimes vacuoles in the periphery. This agrees with the data of $\mathrm{W}$ atzka ('57, women). The corona radiata develops completely in fully grown vesicular follicles at 28 days. The component cells are columnar (fig. 9). They have been described to be accessory nurse cells (Wotton et al., ' 51 , cats), divisible into two types, columnar and squamous, of which cytoplasmic processes reach oocytes through the oolemma. W a tzk a ('57, women) described them to be rod-shaped cells, whose filar processes connect with the oolemma. The present study was not extended to confirm these facts.

Liquor folliculi-Its production has been differently discussed-by the albuminous degeneration of the granulosa (S c hottländer, 1893, some mammals), the transudation from blood vessels of the theca interna ( $\mathrm{Nag}$ e l, 1896, women; Coh n, '03, rabbits; B u r r et al., '51, rabbits), the melting of $\mathrm{C}$ a $1 \mathrm{l}-\mathrm{E} \times \mathrm{n}$ e r's bodies ( $\mathrm{N}$ a $\mathrm{g}$ e l, 1896, women) and the secretion of the granulosa cells ( $\mathrm{Coh}$, '03, rabbits). Kölliker ('02, some mammals) regarded it to be a secretion of the follicular epithelium and partly a transudate originating from metabolized granulosa and ova. Tog a r i ('23) laid greater weight upon transudation rather than upon secretion in mice, while he ('26). recognized both origins in rabbits. The present data may support transudation, because of no other significant change except loosening of cell connection in the follicular epithelium and membrana granulosa. The production of the liquor is very rapid in hamsters. It is impossible to divide primary and secondary fluids (R o b i n s o n, '18, ferrets). Call-Exner's bodies appear as a beginning center of cavity formation at the onset of production of the liquor in the follicular epithelium and membrana and soon in the cumulus (figs. 8 and 9). Around the bodies granulosa cells are not always radially arranged.

Multiovular follicles-have been reported to be biovular chiefly 
in women (Watzka, '57; B u r k l, '57; Schuma cher et al., '00). A r nold ('12) reported follicles containing two to 13 ova per follicle in a negress. In other mammals, the multiovular follicles have been found to contain usually more numerous oocytes than in women. In hamsters, multiovular follicles begin to appear in the deep zone of the cortex at 10 days and later increase in number containing two to 6 ova. The development of the multiovular follicles has been differently discussed-1. from multinucleated ova produced by direct division (Stöcke l, 1899, women), 2. due to incompleteness of ingrowth of connective tissue, by which egg clusters are formed ( $\mathrm{N}$ a g e l, 1888, women; van B e e k, '24, cows), 3. by the development into ova of follicular cells (D a w s o n, '51, rats), and 4. due to direct division of ova and incomplete ingrowth of connective tissue ( $\mathrm{Sch}$ ottlä nde r, 1893, some mammals). In hamsters, very rare cases were found which resembled the data of Daw son. No amitotic division of ova was found in hamsters. It is supposed that multiovular follicles are produced from cell conglomerates and cords due to incomplete ingrowth of connective tissue. D a w s o ('51, rats) found chief and accessory ova in multiovular follicles. This difference is scarcely seen in those of hamsters, and ova are indivisible into two kinds. The fate of multiovular follicles is atresia (W a tz ka, '57, women) and this is true for those of hamsters. In agreement with the view of Watzka ('57, women), it is doubtless that ova of multiovular follicles are far less resistant and most of thern degenerate before they become vesicular.

The theca folliculi-has been reported to appear for the first time as concentrically arranged connective tissue around the primary follicles (Köll i ker, '02, some mammals; Stieve, '30, women ; Kitajima, ' 34 b, women) or around follicles with a few-layered follicular epithelium ( $\mathrm{T} \mathrm{a} \mathrm{j} \mathrm{i} \mathrm{m} \mathrm{a,} \mathrm{'36,} \mathrm{rabbits)} \mathrm{and} \mathrm{to} \mathrm{develop} \mathrm{earlier} \mathrm{than}$ the oolemma ( $\mathrm{Ki}$ t a j i ma, ' $34 \mathrm{c}$, women) or at almost the same time with it (W a ld e y e r, 1870, some mammals). In hamsters, the theca folliculi appears for the first time around the advanced forms of primary follicles at 8 days after birth. The differentiation into two layers, internal and external, has been described to occur before the formation of the follicular cavity ( $\mathrm{Köl} 1 \mathrm{iker}$, '02, some mammals) or at the onset of production of the liquor folliculi (Tog a $\mathrm{i}$, '23, mice; T a j i ma, '36, rabbits). In hamsters, the differentiation occurs in growing follicles at 18 days, which are producing yet no liquor. The cells become polygonal-theca interna cells in the internal 
layer-from fusiform types and are often seen to be in mitosis. In vesicular follicles just before rupture the theca interna cells come to contain vacuoles. This agrees with the data of $\mathrm{Cohn} \mathrm{('03,} \mathrm{rab-}$ bits), Corner ('19, sows), Tog ari ('23, mice) and W t z ka ('57, women) who found the vacuoles in theca interna cells of mature follicles. Strassmann ('34, women) and Möllendorff ('35, women) described the "Thecakeil"-a proliferation of the theca interna which leads mature follicles to extend towards the surface of the ovary. In hamsters, a slight thickening of the theca is found only in an inner area corresponding to the cumulus oviger, but it is not alway's coincident with the direction of extension of vesicular follicles.

Involution-of primary follicles appears as 1. a thickening and hyaline degeneration of the basement membrane, 2. vacuoles of the nuclei and cytoplasm, and shrinkage in ova and, 3. spaces between the stroma and follicles (W at $\mathrm{zka}$, '57, women). The involution begins to occur at about 7 days in hamsters and a little earlier even in egg clusters which contain oocytes just about to enter the beginning stage of meiosis. Involution of growing follicles has been classified into two forms, cystic and atretic ( $\mathrm{S} \mathrm{c} \mathrm{h} \mathrm{r} \mathrm{ö} \mathrm{a} \mathrm{e} \mathrm{r,} \mathrm{'30,} \mathrm{women} \mathrm{;}$ Stieve, '30, women; W at zka, '57, women). The former occurs in large or medium-sized follicles and the latter in small follicles. The former represents a follicular cyst which becomes lined merely by the theca and the latter does not form the cyst. S a k id a ('32, guinea pigs) found both types, but described their development to be reversed in relation to the follicular size. In hamsters, the involution of growing follicles appears exclusively as the atretic forms, which begin to occur at 25 days. Ova show shrinkage, wavy oolemma, - then degeneration and disappearance of their nuclei, cytoplasm and oolemma. The follicular epithelium degenerates through caryorrhexis and pyknosis of the nuclei and swelling of the cell bodies. Involution of vesicular follicles is also atretic but indicates transiently the cystic forms in the course of development to the atretic forms. This is consistent with the data of $\mathrm{Tajima}$ ('36, rabbits). Degenerating ova and other different signs such as scattering in the liquor of granulosa cells, invasion through the basement membrane of histiocytes and fibrocytes, resorption of the liquor and final disappearance of the granulosa are found in the vesicular follicles. The atretic forms of growing and vesicular follicles are finally transformed through thickening and hyalination of the base- 
ment membrane and its neighborhood into the corpora albicantia. During the involution, the theca rather proliferates through mitotic division and hypertrophy of theca interna cells.

Sakaida ('32) described in guinea pigs before and after puberty that the polar spindle and body appear in involution of medium-sized or large follicles, and suggested that the production of the polar body, which may be considered as an ultimate fate of the ova, is prematurely provoked by the involution. This phenomenon is also found in hamsters, but some points are different. It occurs only in grown vesicular follicles in and after puberty but not in medium-sized ones before puberty.

Corpora lutea-Their development presents three different aspects which remain in dispute. Some supported the development from the granulosa (Sobotta, 1896, mice; Cohn, '03, rabbits; Togari, '23, mice ; C or ne $r$, '19, sows), on the observation of transformation of theca interna cells into fusiform cells which produce merely connective tissue reticulum without contributing to the production of lutein cells. Togari ('23, mice) added the degeneration of theca interna cells in agreement with this view. The corpora lutea are formed by mitotic division (Togari, '26, rabbits) and hypertrophy (S o botta, 1896, mice; Cohn, '03, rabbits; Tog a r i, '23, nice: '26, rabbits) of granulosa cells. The luteinization of the granulosa has been said to occur immediately ( $\mathrm{Cohn}$, '03, rabbits) or shortly (Togari, '26, rabbits) after rupture. Others insisted the development from the theca ( $\mathrm{Nagel}$, 1888, women; Schott l ä n d e r, 1893, some mammals; T a j i m a, '36, rabbits) and observed 1. the degeneration of the granulosa after rupture, and 2 . hypertrophy and mitotic division of the theca interna and transformation into lutein cells. Still others asserted origin from both sources (S e i tz, '06, women; C o h n, '09, women).

Corpora lutea of hamsters appear for the first time at 30 days. Immediately after rupture, granulosa and theca interna cells indicate some signs of transformation into lutein cells-hypertrophy and mitotic division. The theca interna cells accumulate as lutein cells at the base of the folds of the layer of granulosa lutein cells. Later, both kinds become indistinguishable. The connective tissue reticulums are formed by cells of the theca externa and some theca lutein cells are seen returning to connective tissue cells. This agrees with the data of Tog a r i ('23, mice). The vascularization proceeds in parallel with the reticular development of connective tissue and 
extends further towards the inner layer. This agrees with the data of $\mathrm{B} \mathrm{a} \mathrm{ch} \mathrm{mann} \mathrm{('36,} \mathrm{women)} \mathrm{and} \mathrm{W}$ a t $\mathrm{zk}$ a ('57, women). W a t z ka pointed out the extension of blood vessels towards the inner layer of the corpora.

Regression in corpora lutea extends from the center to the periphery in hamsters and brings about the development of corpora fibrosa at 38 days through degeneration of lutein cells and that of corpora albicantia at 40 days through hyaline degeneration. The lutein cells have been described to show mitotic division, reduction of nuclear size, clotting of chromatin and vacuole formation in the cytoplasm (W at zka, '57, women). Almost the same phenomenon occurs in corpora of hamsters and further a conspicuous increase of argyrophilic fibers, which invade lutein cells to separate, occur. The vacuoles in the cytoplasm may be due to the presence of lipid. Togari ('24, mice) found two fates in lutein cells-fat degeneration and transformation into pigment cells. In hamsters transformation is not found.

Interstitial cells-There are several different views on their differentiation. C o h n ('03, rabbits), A s chner ('14, women) and S ti e ve ('30, women) stated that they develop from theca cells having proliferated in regressing follicles. Winiwarter ( 08 , women) regarded them to develop from connective tissue cells from the observation of the transitional forms found near and between both the rete ovarii and medullary cords. Fis chel ('30, women) supported this view. Tajima ('36, rabbits) pointed out differentiation and growth from stroma cells found in the cortex and medulla. $\mathrm{Koh} \mathrm{n}$ ('26, horses) considered them to develop from the germinal epithelium, medullary cords and follicular epithelium. Tsukaguchi et al. ('28) observed in dogs that they develop from elements of medullary cords dissolving in the interstitium. Recently, Patzelt ('55, '56, some mammals) emphasized that they differentiate from the cells of the polyvalent blastem-mesenchymal cells, theca cells and genital cords. The onset of appearance of the interstitial cells is different in different animals. W i n i w a r te r ('08) and F i s che l ('30) found them in $40 \mathrm{~mm}$ human fetuses and A s chner ('14) in those of 5 months. Tsukaguchi et al. ('28) found them in puppies at three days after birth, and $\mathrm{Tajima}\left({ }^{\prime} 36\right)$ in rabbits two months old. They have been described to be numerous until puberty but thereafter reduced. T a ji m a ('36) observed in rabbits that they complete differentiation at puberty and thereafter represent a main component 
of the ovary.

In hamsters there occurs development into interstitial cells only in postnatal life. They develop from two sources. One differentiates from connective tissue cells in the hilus with some modification of round eosinophilic nuclei and eosinophilic granular cell bodies from 12 days on (fig. 7.) They increase not so numerously but disappear soon-at about 60 days. The other develops from theca interna cells of regressing follicles from 35 days on (figs. 14 and 15), and increases so numerously that they occupy almost the entire extent of the ovary at 50 days. Later, they decrease through degeneration. It is further found that interstitial cells of both origins revert in part to connective tissue cells. The results conform to those of $\mathrm{W}$ a t z k a (' 57 , women). K o h n ('26, horses) observed their degeneration while Stieve ('30, women) suggested their conversion to stroma cells.

\section{Summary}

Histological investigations of prenatal and postnatal development of the ovary of hamsters elucidated the following: Development is divisible into three stages: 1 . The indifferentiation stage (approximately 6 to $11 \mathrm{~mm} \mathrm{CRL,} 10$ to 12 days of gestation): Where the primordium indicates no sex, appears as a few-layered thickening of the celomic epithelium-germinal epithelium containing primordial germ cells-on the ventromedial surface of the mesonephros, which soon proliferates actively into cell conglomerates to fill the entire extent of the primordium. 2. The preparatory differentiation stage subdivisible into two parts: In the first part the cell conglomerates develop into cords in the deep zone of the primordium-medullary cords in $14 \mathrm{~mm}$ (13 days) and in the superficial zone cortical cords in about $21 \mathrm{~mm}$ (14 days). Thus, the primordium is identifiable as the female sex at 14 days. In the second part (approximately 28$32 \mathrm{~mm}, 15-16$ days) the cords are seen separating into egg clusters which further divide into smaller ones. During these stages, the primordial germ cells-oogonia-in the germinal epithelium increase by mitosis and are added in order to the cell conglomerates, medullary and cortical cords and their clusters, but at almost the same time degeneration begins to occur and continues until later.

3. The definitive differentiation stage (from immediately after birth to adult): This stage contain many important changes leading to the final development of the ovary. Oogonia change to oocytes 
passing through the beginning stages of meiosis. The oocytes enter a stage of rest after the diplotene stage and grow with the formation of follicles. The proliferation of the germinal epithelium is now ceasing with the formation of the tunica albuginea and remains as small invaginations which contain no mitotic figures of oogonia after 4 days nor meiotic figures of oocytes after 10 days.

Medullary cords become vestigal with gradual degeneration of oocytes contained, and disappear at 8 days. The rete ovarii, which appears as cell conglomerates in the hilus at the $14 \mathrm{~mm}$ stage of prenatal life, is found as a tube shortly after birth and later becomes a branched acinous structure.

The differentiation of follicles is centrifugal-follicles are in more advanced development in the deep zone of the cortex. Primary follicles appear for the first time in the deep zone of the cortex at 6 days and growing follicles at 10 days. Vesicular follicles extend towards the surface of the ovary at 28 days.

The stratification of follicular epithelium undergoes mitotic division. The oolemma is found in oocytes of follicles with severallayered folicular epithelium at 15 days. Liquor folliculi is produced by transudation from the blood vessels of the theca interna, and the follicular cavity originates from the bodies of $\mathrm{C}$ a ll-Ex $\mathrm{E}$ e $\mathrm{r}$ wich exist between granulosa cells. Multiovular follicles occur in the deep zone of the ovary from 10 days on. The theca folliculi is found as a layer of connective tissue around grown primary follicles at 8 days and develops to the theca interna and externa in growing follicles at 18 days.

Corpora lutea appear for the first time at 30 days passing through conversion to lutein cells of granulosa and theca interna cells, which begin already just before rupture, corpora fibrosa through centrifugal degeneration of lutein cells, ingrowth of connective tissue of the theca and partly reversion to connective tissue cells of theca lutein cells at 38 days, and corpora albicantia through hyaline degeneration at 40 days.

Involution begins to occur in primary follicles at 7 days, in growing follicles at 25 days and in vesicular follicles at 28 days. The involution is atretic but not cystic. Atretic vesicular follicles only indicate transiently the cystic form. Degeneration starts usually in oocytes but sometimes in the follicular epithelium or in the - membrana granulosa. Oocytes of atretic vesicular follicles indicate often polar spindles and polar bodies. Multiovular follicles involute. 
rapidly and disappear at 60 days.

Interstitial cells are distributed more or less extensively as cell islets in the cortex and medulla and are of two origins. One develops from connective tissue cells at 15 days and consists of polygonal cells which have round to oval eosinophilic nuclei and eosinophilic granular cytoplasm, while the other develops from the theca interna cells of regressing follicles at 35 days and consists also of polygonal cells which have irregular-shaped chromatin-rich nuclei and clear cytoplasm. The former increases not so actively but at a rather earlier period of 60 days disappears, while the latter increases actively.

The author wishes to acknowledge his sincere thanks to Prof. Dr. Shoo i chi Sug i y ma for his kind guidance throughout the course of this study. The author is also indebted to Prof. Dr. $\mathrm{Chikat}$ a ro Togari for kind encouragement and help.

\section{Literature cited}

A $11 \mathrm{e}$, B. M.: The embryonic development of the ovary and testis of mammals. Am. J. Anat., 3: 89-146, 1904.

Arai, H.: On the postnatal development of the ovary (albino rat) with especial reference to the number of ova. Am. J. Anat., 27:405-462, 1920.

Arnold, L.: Adult human ovaries with follicles containing several oocytes. Anat. Rec., 6 : 413-422, 1912.

Ashner, B.: Über Morphologie und Funktion des Ovariums unter normalen und pathologischen Verbältnissen. Arch. Gynäk., 102: 446-510, 1914.

$\mathrm{Bachmann}$, R.: Untersuchungen über den Ovulationstermin nebst Bemerkungen zur Histologie des Corpus luteum. Z. mikr.-anat. Forsch., 40: 57-109, 1936.

B arton, E.P.: Cyclic changes of epithelial cords in dog ovary. J. Morph., 76 : 317-347, 1945.

B üh le r, A.: Geschlechtsdrüsen der Säugestiere. In: Hertwig's Handb. d. vergl. u. exper. Entw. d. Wirbeltiere, Gustav Fischer, Jena, 716-724, 1906.

Burkl, W.: Die Neubildung von Primärfollikeln vor und nach Begin der Geschlechtsreif bei verschiedenen Säugetieren. Z. Zellforsch., 43: 345-382, 1955. : Betrachtungen zum Problem der postnatalen Oogenese nebst einigen Befunden in den Ovarien geschlechtsreifer Frauen. Z. mikr.-anat. Forsch., 63: 131-144, 1957.

B u r r, J.H. Jr. and J.I. Davies: The vascular system of the rabbit ovary and its relationship to ovulation. Anat. Rec., 111: 273-297, 1951.

Butcher, E.O.: The origin of the definitive ova in the white rat. Anat. Rec., 37: 13-30, 1927.

$\mathrm{Ch}$ a u d hry, H.S.: The origin and structure of the zona pellucida in the ovarian eggs of teleosts. Z. Zellforsch., 43: 478-485, 1956.

$\mathrm{Chiquoine}$ A.D.: The identification, origin and migration of the primordial germ cells in the mouse embryo. Anat. Rec., 118: 135-145, 1954. 
Coert, H.J.: Over de ontwikkeling en den bouw van den geschlachtsklier bij de zoogdieren meer in het bijzonder van den eierstok. Diss. inaug. Leinen, 1898 (cited from B ühl e r, 1906).

Cohn, F.: Zur Histologie und Histogenese des Corpus luteum und des interstitiellen Ovarialgewebes. Arch. mikr. Anat., 62: 745-772, 1903.

: Über das Corpus luteum und den atretischen Follikel des Menschen und deren cystischen Derivate. Arch. Gynäk., 87: 367-444, 1909.

Corner, G.W.: On the origin of the corpus luteum of the sow from both granulosa and theca interna. Am. J. Anat., 26: 117-183, 1919.

Dawson, A.B.: Histogenetic interrelationships of oocytes and follicle cells. A possible explanation of the mode of origin of certain polyovular follicles in the immature rat. Anat. Rec., 110: 181-197, 1951.

Duke, K.L.: The germ cells of the rabbit ovary form sex differentiation to maturity. J. Morph., 69: 51-75, 1941.

Evans, H.M., R. McLea n and O. Swe zy: Oogenesis and the normal follicular cycle in adult mammals. Memoirs Univ. Calif., 9: 119-224, 1931 (cited from B u r k 1, 1957).

Everett, N.B.: Observational and experimental evidences relating to the origin and differentiation of the definitive germ cells in mice. J. Exper. Zool., 92: 49-92, 1943 (cited from $W$ at $z \mathrm{ka}$ a 1957).

Felix, W.: Entwicklung der weiblichen Genitalien. In: Keibel-Mall's Handb. d. Entw., 2: 1911 (cited from Schrö der, 1930).

Fischel, A.: Die Entwicklung der Organe. In: Handb. d. Entw. d. Mensch., 609-617, Julius Springer, Wien u. Berlin, 1929.

-: Über die Entwicklung der Keimdrüse des Menschen. Z. Anat., 92: 34$72,1930$.

Fuss, A.: Über die Geschlechtszellen des Menschen und der Säugetiere. Arch. mikr. Anat., 81: 1-23, 1912.

Gi $11 \mathrm{ma} \mathrm{n}, \mathrm{J}$.: The development of the gonads in man, which a consideration of the role of fetal endocrines and the histogenesis of ovarian tumors. Contrib. to Embryol., 32: 81-131, 1948 (cited from $W$ a t $z$ k a, 1957).

Gr ünwald, P.: Über Form und Verlauf der Keimstränge bei Embryonen der Säugetiere und des Menschen. II. Die Keimstränge des Eierstockes. Z. Anat., 103 : 259-277, 1934.

: The development of the sex cords in the gonads of man and mammals. Am. J. Anat., 70: 345-396, 1942.

$\mathrm{H}$ a m lett, G.W.: Primordial germ cells in a $4.5 \mathrm{~mm}$ human embryo. Anat. Rec., 61: 273-280, 1935.

Hargitt, G. T.: The formation of the sex glands and germ cells of mammals. I. The origin of the germ cells in the albino rat. J. Morph., 40:555-577. 1925.

Higuchi, K.: Über die erste Anlage der menschlichen Keimdrüse und ihre geschlechtliche Differenzierung. Arch. Gynäk., 149: 144-172, 1932.

J a n os i k, J.: Histologisch embryologische Untersuchungen über des Urongenitalsystem. Sitz. Akad. Wiss. Wien, 91: 1885 (cited from Bü h 1 e r, 1906).

: Bemerkung über die Entwicklung des Genitalsystem. Sitz. Akad. Wiss. Wien, 96: 1890 (cited from $S$ a k a id a, 1932).

J ung, P.: Die Entwicklung des Schwein-Eierstockes bis zur Geburt. Z. mikranat. Forsch., 41 : 23-74, 1937. 
Kimura, M.: On the early development of the gonad in cat. Studies from the Department of Anatomy, Hiroshima University School of Medicine, 5: 3147, 1959.

Kingery, H. M.: Oogenesis in the white mouse. J. Morph., 30: 261-316, 1917 (cited from $\mathrm{K}$ i m u r a, 1959).

$\mathrm{King} \mathrm{sbury,} \mathrm{B.F.:} \mathrm{The} \mathrm{morphogenesis} \mathrm{of} \mathrm{the} \mathrm{mammalian} \mathrm{ovary:} \mathrm{Felis} \mathrm{domes-}$ tica. Am. J. Anat., 15: 345-388, 1913.

- Atresia and the interstitial cells of the ovary. Am. J. Anat., 65: 309-331, 1939.

Kitajima, H.: Beiträge zur Erkenntnis der Entwicklung des Eifollikels im Ovarium, besonders Epitheles, beim menschlichen Embryo. Nagasaki Igakkwai Zasshi, 12: 1308-1355, 1934 a.

: Über die Entwicklungsperiode der Theca folliculi beim menschlichen Embryonal-follikel. Nagasaki Igakkwai Zasshi, 12: 1564-1579, 1934 b.

: Über die Entwicklungsperiode von Zona pellucida beim menschlichen Embryonal-follikel. Nagasaki Igakkwai Zasshi, 12: 1581-1591. 1934 c.

Kölliker, A.v.: Über die Entwicklung der Graafschen Follikel und Eier. Sitzgsber. physiol.-med. Ges. Würzburg, 1898 (cited from Köl1iker, 1902).

- : Entwicklung des Eierstockes, der Eisackchen und der Eier im Allgemeinen. In: Handb. d. Gewebelehre d. Mensch., 3: Wilhelm Engelmạnn, Leipzig, 1902.

Kohn, A.: Über den Bau des embryonalen Pferdeeierstockes. (Ein Beitrag zur Kenntnis der Zwischenzellen). Z. Anat., 79: 366-390, 1926.

Marschall, A.: The physiology of reproduction. London, 1910 (cited from Ch a u d h ry, 1956).

Möllendorff, E.v.: Der theca interna-Keil, eine typische Bildung wachsender Säugetierfollikel. Arch. Gynäk., 160:278-301, 1935 (cited from Wa t $z \mathrm{k}$ a, 1957).

Na g e l, W.: Das menschliche Ei. Arch. mikr. Anat., 31: 342-423, 1888.

: Die weiblichen Geschlechtsorgane. In: Bardeleben's Handb. d. Anat. d. Mensch., VII/I, Gustav Fischer, Jena, 42-56, 1896.

$\mathrm{Nieuwk}$ oop, P.D.: The present state of the problem of the "Keimbahn" in the vertebrates. Experimentia, 8: 308-312, 1949.

Ok a moto, T.: Über den Ursprung des Follikelepithels des Eierstockes beim Hunde. Fol. anat. jap., 6: 689-702, 1928.

Pat zelt, V.: Über das Ovarium der Karnivoren und $Z$ wischenzellen. Z. mikr. -anat. Forsch., 61: 309-359, 1955.

-: Der Eierstock der Säugetiere und die Phylogenese. Erg. Anat., 35: 99132, 1956.

Po! it z er, G.: Die Keimbahn des Menschen. Z. Anat., 100: 331-361, 1933.

Pratt, B.H. and J.A. Long: The period of synapsis in the egg of the white rat. J. Morph., 29: 1917 (cited from S a k a i d a, 1932).

Robinson, A.: The formation, rupture and closure of ovarian follicles in ferrets and ferret-polecat hybrids and some associated phenomena. Trans. Roy. Soc. Edinburgh, 52: 302-362, 1918 (cited from W a t $z \mathrm{k} \mathrm{a}, 1957$ ).

$\mathrm{Rub}$ aschkin, W.: Zur Lehre von der Keimbahn bei Säugetieren. Über die Entwicklung der Keimdrüsen. Anat. Hefte., 46: 345-411, 1912.

$\mathrm{S}$ ak a ida, H.: Histogenetische Untersuchung des Meerschweicheneierstocks, be- 
sonders über die Oogenese desselben. Nissanpushi, 27 : 1786-1817, 1933-1960, 3005-3036, 1932.

Schottländer, J.: Über den Graafschen Follikel, seine Entstehung beim Menschen und seine Schicksale bei Mensch und Säugetieren. Arch. mikr. Anat., 41 : 609-617, 1893.

Schröder, R.: Die weiblichen Genitalorgane. In: v. Mölle ndorf f's Handb. d. mikr. Anat. d. Mensch., VII/I, 329-335, Julius Springer, Berlin, 1930.

Schumacher, S. v. und C. Schwarz: Mehrkernige Eizellen und mehreiige Follikel. Anat. Anz., 18: 1-8, 1900.

Seit $z$, L.: Die Follikelatresie während der Schwangerschaft, inbesondere die Hypertrophie und Hyperplasie der Theca-interna (Theca Luteinzellen) und ihre Beziehung zur Corpus luteum-Bildung. Arch. Gynäk., 77 : 203-356, 1906.

$\mathrm{S}$ i m k i ns, Cl.S.: On the origin and migration of the so-called primordial germ cells in the mouse and the rat. Acta. Zool., 4: 1923 (cited from Ki m u ra, 1959).

Skrobansky, K.: Beiträge zur Kenntnis der Oogenese bei Säugetieren. Arch. mikr. Anat., 62: 607-668, 1903.

Sobotta, J.: Über die Bildung des Corpus luteum bei der Maus. Arch. mikr. Anat., 47: 261-308, 1896.

St i eve, H.: Beobachtungen an menschlichen Eierstöcken. Z. mikr.-anat. Forsch., 22: 591-659, 1930.

Stöcke 1, W.: Über die Teilungsvorgänge in Primordialeiern bei einer Erwachsenen. Arch. mikr. Anat., 53: 357-384, 1899.

Strassmann, E.: Eizelle und Follikel bei vitaler Färbung. Z. Geburtsh., 105: 1933 (cited from W at $z \mathrm{ka}$, 1957).

-_- Theca interna-Keil des Wegbahner des Follikels. Arch. Gynäk., 158: 628-638, 1934 (cited from W a t $z \mathrm{k}$ a, 1957).

Taji ma, A.: Studien über die Entwicklung des Kaninchenovarium. Kaibo. Z., 9: 471-490, 1936.

Tog a ri, Ch.: On the origin of corpus luteum of the mouse. Aichi J. exp. med., 1, No. 2: 1-54, 1923.

- : On the retrogression of the corpus luteum of the mouse. Aichi J. exp. med., 1, No. $4: 1-17,1924$.

- $:$ On the corpus luteum of the rabbit. Fol. anat. jap., 4:337-362, 1926.

Tsuk a g c hi, R. und T. Ok a moto: Der Ursprung der interstitiellen Zellen des Ovariums beim Hunde. Fol. anat. jap., 6: 663-687, 1928.

V an Beek, W.F.: Die Entwicklung des Eierstockes beim Rinde. Z. Anat., 71 : 458-558, 1924.

W a 1 d e y er, W.: Eierstock und Ei. Leipzig, 1870 (cited from Sak a d a, 1932).

- Die Geschlechtszellen. In: Hertwig's Handb. d. vergl. u. exper. Entw. d. Wirbeltiere, I: Gustav Fischer, Jena, 86-476, 1906.

W a t z k a, M.: Die weibliche Genitalorgane. Das Ovarium. In: v. Möllendorff's Handb. d. mikr. Anat. d. Mensch., VII/I: Julius Springer, Berlin, 1957.

Wils o $n, K . W .:$ Origin and development of the rete ovarii and the rete testis in the human embryo. Contrib. to Embryol., 86: 69-88, 1926.

W in i warter, H.v.: Recherches sur l'ovogenése et l'organogenése de l'ovaire des mammiféres (lapin et homme). Arch. Biol., 17: 33-199, 1901 (cited from $\mathrm{K}$ ö 11 i k e r, 1902).

— : Das interstitielle Gewebe der menschlichen Ovarium. Anat. Anz., 33: 
$1-9,1908$.

: La constitution et l'involution du corps de Wolff et le développement du canal de Müller dans l'espéce humaine. Arch. Biol., 25: 169-267, 1910 (cited from Wils o n, 1926).

W in i wart e r, H. v. et G. S a in m o n t: Recherches sur l'ovogenése et l'organogenése de l'ovaire des mammiféres (lapin et homme). Arch. Biol., 17: 1900 (cited from Sak a ida, 1932).

- Nouvelles recherches sur l'ovogenése et l'organogenése de l'ovaire des mammiféres (chat). Arch. Biol., 24: 1909 (cited from $\mathrm{R} \mathrm{u} \mathrm{b}$ a s ch k i n, 1912).

Witschi, E.: Migration of the gern cells of human embryos from the yolk sac to the primitive gonadal folds. Contrib. to Embryol., 32: 69-80, 1948 (cited from $W$ a t $z \mathrm{k}$ a, 1957).

Wotton, R.M. and P.A. Village: The transfer function of certain cells in the wall of the Graafian follicle as revealed by their reaction to previously stained fat in the cat. Anat. Rec., 110: 121-127, 1951.

\section{Explanation of plate figures}

All figures except figure 3 represent photomicrographs of sections of ovaries and their primordia of hamsters, which were stained with hematoxylin and eosin.

1. $6 \mathrm{~mm} \mathrm{CRL} \mathrm{(10} \mathrm{days} \mathrm{of} \mathrm{gestation).} \mathrm{Primordial} \mathrm{germ} \mathrm{cells} \mathrm{(black} \mathrm{arrows)}$ are seen in the germinal epithelium (GE), mesenterial root (MR) and their underlying mesenchym $(M) . \times 320$.

2. $21 \mathrm{~mm} \mathrm{CRL} \mathrm{(14} \mathrm{days} \mathrm{of} \mathrm{gestation).} \mathrm{Medullary} \mathrm{(MC)} \mathrm{and} \mathrm{cortical} \mathrm{(CC)} \mathrm{cords}$ which contain oogonia are found. Here, oogonia (white arrows) are seen as cells with chromatic nuclei and dark eosinophilic cytoplasm. Primitive connective tissue and blood vessels are seen invading from the hilus. $\times 160$.

3. $28 \mathrm{~mm}$ CRL (15 days of gestation). Medullary and cortical cords are now separating into egg clusters of various sizes by ingrowth of connective tissue (argyrophilic fibers). The egg clusters remain in considerable part still connected with others. Just beneath the germinal epithelium, a primitive tunica albuginea (white arrows) is formed. Bielschowsky's silver impregnation. $\times 160$.

4. 3 days after birth. The cortex. Oogonia (black arrows) have round nuclei and enlarged clear cell bodies. Oocytes (white arrows) are in meiotic division (most of them in the synaptene stage). Ordinary epithelial cells (asterisks) have nuclei with loose chromatin reticulum and clear cell bodies. $\times 650$.

5. 6 days after birth. The cortex. Primary follicles (fine black arrows) are now in formation with the differentiation to follicular cells of ordinary epithelial cells. Some oocytes are in meiotic division (heavy black arrows) and some in degeneration (asterisks). $\times 320$.

6. 15 days after birth. The germinal epithelium is flat but maintains some invaginations. Primary follicles are seen in the superficial zone of the cortex and growing follicles in the deep zone. The growing follicles have severallayered follicular epithelium and contain oocytes with a distinct oolemma. The theca folliculi is formed around them. $\times 160$.

7. 18 days after birth. Islets of interstitial cells (white arrows) which develop from connective tissue cells are shown. The interstitial cells are eosinophilic, and appear somewhat darker than those of theca interna cell origin. The nuclei are more regularly round to oval. One of them is in mitotic division 
(heavy white arrow). A primary follicle without the theca folliculi is found. $\times 320$.

8. 25 days after birth. A growing follicle is shown. A few bodies of CallExner (white arrows) occur as a beginning sign of formation of the follicular cavity. Follicular cells are arranged in part loosely and in part densely. The theca is developing into the theca interna (THI) and externa (THE). $\times 160$.

9. 28 days after birth. A Graafian follicle is shown. Bodies of Call-Exner (white arrows) are seen in the cumulus oviger. The theca is well developed. The theca interna is thick in the inner part corresponding to the cumulus. $\times 150$.

10. 28 days after birth. Involution of a Graafian follicle is shown. Granulosa cells are in degeneration. Their nuclei are pyknotic and caryorrhexic. Cell debrises are scattered within the cavity. The oocyte indicates a polar spindle and a polar body. Theca interna cells (THI) increase in number. $\times 320$.

11. 30 days after birth. Several growing follicles are in involution (atresia, fine white arrows). Degenerated oocytes show shrinkage of the cell bodies and a wavy oolemma. The follicular epithelium is also in degeneration. The theca interna (heavy white arrows) is now growing. $\times 80$.

12. 30 days after birth. A fresh corpus luteum just after rupture. The membrana granulosa remains still without throwing into folds. Granulosa cells and theca interna cells are changing to lutein cells. $\times 80$.

13. 30 days after birth. An advanced corpus lutem. The folded layer of lutein cells is shown. Both kinds of lutein cell, granulosa and theca, are hypertrophic and indistinguishable in appearance. Blood vessels and connective tissue invade radially towards the center of the corpus passing through the folded layer. $\times 80$.

14. 35 days after birth. Interstitial cells are developing from theca interna cells of atretic follicles. Around a degenerated oocyte (black arrow) the interstitial cells accumulate as cords. They have somewhat irregularly round to oval chromatic nuclei and clear cell bodies. $\times 160$.

15. 40 days after birth. A corpus fibrosum is shown. In the peripheral zone of the corpus, lutein cells (black arrows) are still found but in part in degeneration. In the left lower corner of this figure, interstitial cells (IC) of theca interna cell origin are seen as cords. $\times 80$. 


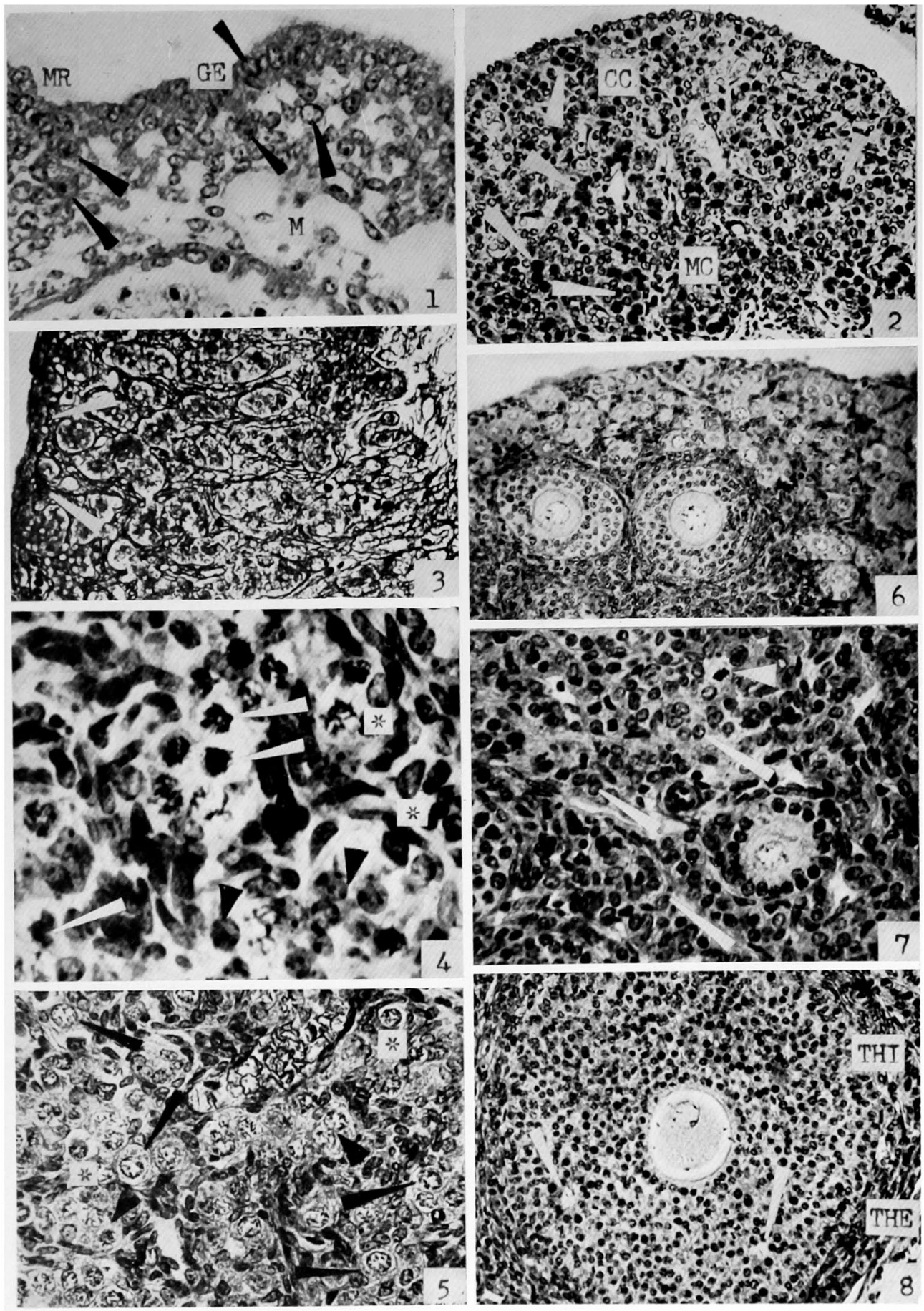
A. Nakano 
Plate II
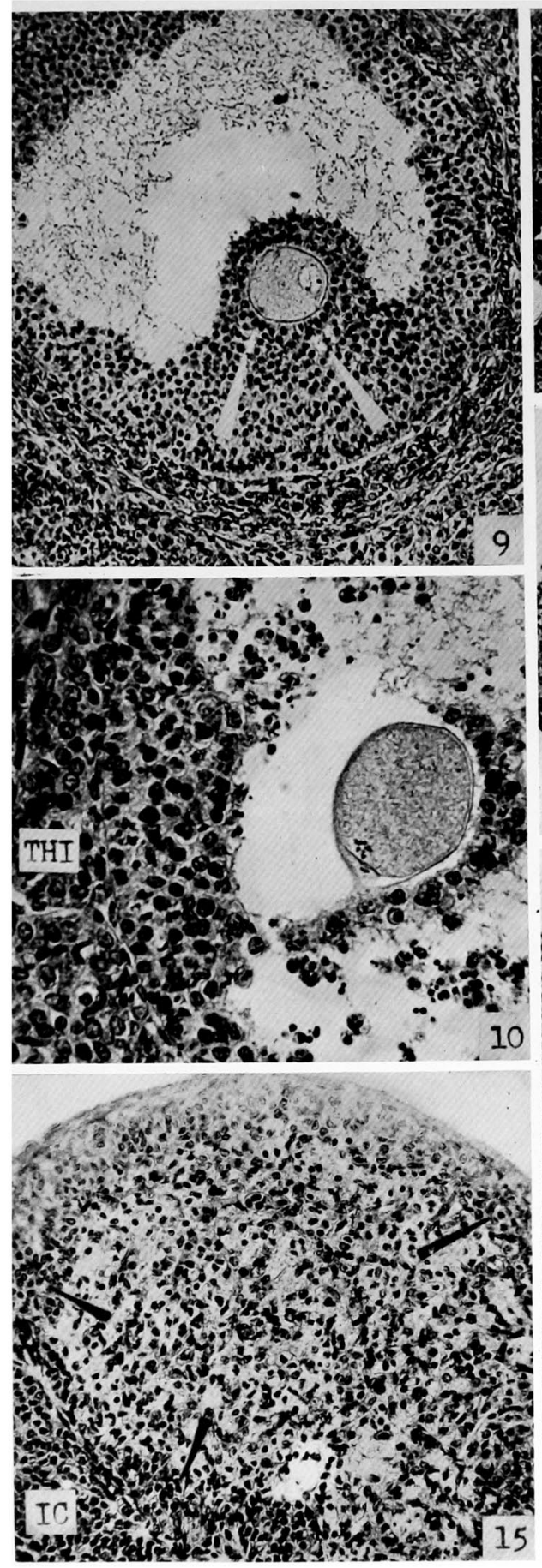
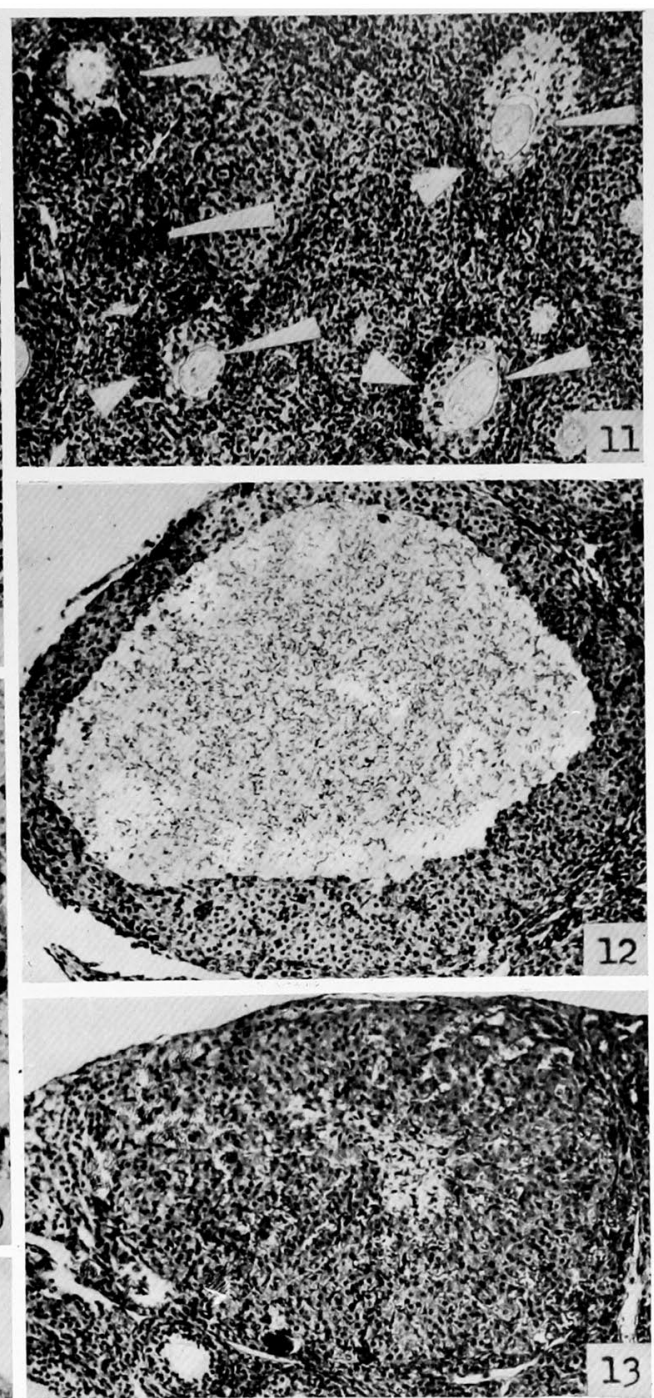

Eक

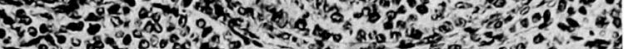

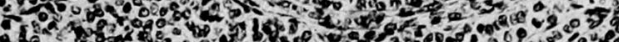

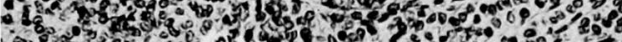
OS 50 \% 5.

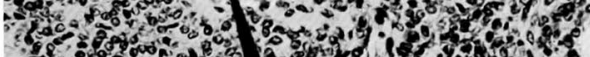

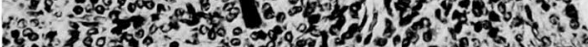

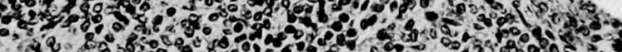

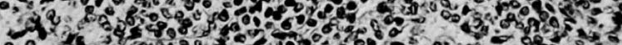

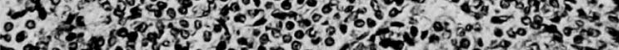
30 H.

A. Nakano 